\title{
Enigmatic PreS deletions in hepatitis B virus DNA
}

\author{
Wolfram H. Gerlich ${ }^{1}$. Dieter Glebe ${ }^{1}$
}

Received: 15 October 2020 / Accepted: 22 October 2020 / Published online: 5 November 2020

(c) The Author(s) 2020

In this issue of Virus Genes, Ting Wang et al. describe a defective variant of hepatitis B virus (HBV) with a very high replication capacity comprising a large deletion in the preS1 domain of the open reading frame encoding the three (large, middle, and small) HBV surface proteins (LHBs, MHBs, and SHBs) [1]. The variant was isolated and cloned from the serum of a patient suffering from chronic hepatitis $\mathrm{B}(\mathrm{CHB})$ who had experienced an HBV breakthrough under antiviral therapy with the nucleotide analog adefovir.

The variant showed the typical mutations A181T and $\mathrm{N} 236 \mathrm{~T}$ in the reverse transcriptase domain of the viral polymerase protein leading to adefovir resistance after previously failed lamivudine therapy. The first lamivudine-selected mutation (A181T) happens to generate the stop mutation W172* in the overlapping S domain of the HBs proteins causing carboxyterminal truncation and intracellular retention of all three HBs proteins. While this is an additional stop mutation in the $\mathrm{S}$ domain $\left(\mathrm{C} 69^{*}\right)$ that prevented the formation and release of enveloped HBV particles encoded by the variant, HBV DNA and HBsAg of the variant could nevertheless be detected in the patient serum. This indicated that the patient's hepatocytes replicating the variant via circular covalently closed (ccc) HBV DNA contained HBV genes encoding functional HBs proteins as well, most likely as linear-integrated HBV DNA fragments. Transcomplementation with functional HBs genes of defective ccc DNA has recently been shown in CHB patients by Peiffer et al. [2].

Surprisingly, the variant described in [1] with the 68 amino acid long preS1 deletion replicated HBV DNA much more efficiently than wildtype (WT) HBV DNA of the same HBV subgenotype $\mathrm{C} 2$ when transfected into the HBV permissive hepatoma cell line Huh7. The variant contained also two mutations in the core promoter (A1762T/G1764A) which are known to enhance HBV replication since long [3],

Wolfram H. Gerlich

wolfram.h.gerlich@viro.med.uni-giessen.de

1 Institute for Medical Virology, Justus Liebig University Giessen, Giessen, Germany but the authors of ref [1] could elegantly prove that the major effect on replication came from the preS1 deletion. When the deleted sequence was artificially re-introduced into the variant, the replication decreased to levels comparable to WT. In addition to enhanced replication, the deletion variant showed a profoundly changed intracellular localization of the $\mathrm{HBV}$ core $(\mathrm{HBc})$ protein from predominantly cytoplasmic to almost exclusively nuclear although the $\mathrm{HBc}$ protein was unchanged.

Both effects are probably linked together. The preS1 sequence (aa 42-110) deleted in the variant of [1] includes the binding site (aa 103-124) of the LHBs protein to mature $\mathrm{HBc}$ particles containing replicated HBV DNA. This binding initiates envelopment of $\mathrm{HBc}$ particles and secretion of mature HBV particles [4]. The naked HBc particles remain initially cytoplasmic but can be subject to nuclear import as has been shown for infectious HBV after removal of the HBs envelope [5]. After nuclear entry, the partially doublestranded virion HBV DNA is released from $\mathrm{HBc}$ particles, converted to cccDNA, and can enter new replication cycles while the core protein can re-assemble to empty nonfunctional HBc particles [5]. This leads to the phenotype which is described in [1].

At the first glance, the variant may appear irrelevant because it cannot generate infectious HBV progeny. However, the large amounts of partially double-stranded HBV DNA accumulating in the nucleus in absence of functional HBs proteins are subject to potentially detrimental cellular DNA repair processes including integration of HBV DNA fragments. Thus, mutated HBs proteins may directly contribute to pathogenesis of HBV-related diseases like hepatocellular carcinoma (HCC) via the effect of intranuclear accumulation of HBV DNA. In fact, HBV variants with altered HBs structure including preS deletions have increasingly been identified in patients with active HBV disease including HCC [6]. Besides the effect of the enhanced HBV DNA replication, the nonsecreted HBs proteins of the variant may contribute directly to pathogenesis and oncogenicity. WT HBV expresses the preS2 domain as part of MHBs and LHBs which assemble with an excess of SHBs protein 
to HBV and subviral HBsAg particles ready for secretion. Disturbance of assembly and blocked subsequent secretion occurs with C-terminally truncated HBs proteins or in the absence of WT SHBs as in the case of the variant described in ref [1].

Already decades ago, secretion-defective HBs mutants, e.g., a truncated form of the middle HBs protein $\mathrm{MHBs}^{\mathrm{t}}$, have been linked to the development of hepatocellular carcinoma (HCC) [7]. Accumulation of HBs proteins causes ER stress and may contribute to development of HCC [8]. However, ER stress may not be the only or main oncogenic mechanism of mutated HBV variants. The preS2 domain is known to carry a small transcription transactivating domain if present in the cytosol, may it be part of $\mathrm{MHBs}^{\mathrm{t}}$ [7] or of WT LHBs [9]. The preS2 domain of LHBs or MHBs could still be expressed by the deletion variant of ref [1]. Although ref [1] did not study this aspect or oncogenicity of the variant, other studies $[10,11]$ have shown that preS2 epitopes can be very often detected in HBV-related HCC tissue and a partial MHBs protein covering the entire preS2 sequence was shown to transactivate oncogenesis supporting genes, e.g., hTERT [10].

Seemingly contrary to the published association of preS2 with HCC $[10,11]$, a high prevalence of preS deletions, both in preS1 and/or preS2, has recently been reported in sera of HCC patients [12]. Remarkably, patients who experienced recurrence of the HCC after surgical removal had a significantly higher proportion of HBV DNA with certain combinations of preS deletions than patients without recurrence [12]. Ref [12] provides no hints on the mechanisms inducing oncogenesis by the various deletions, but an enhanced replication of HBV DNA and its nuclear accumulation as shown in ref [1] would be plausible candidates among many others.

The fact that the highly replicating HBV variant of ref [1] was found in a patient after failed adefovir therapy following lamivudine resistance illustrates the potentially detrimental results of suboptimal antiviral HBV drug therapies facilitating inaccurate viral replication and generation of defective HBV genomes with enhanced pathogenicity.

Funding Open Access funding enabled and organized by Projekt DEAL.

Open Access This article is licensed under a Creative Commons Attribution 4.0 International License, which permits use, sharing, adaptation, distribution and reproduction in any medium or format, as long as you give appropriate credit to the original author(s) and the source, provide a link to the Creative Commons licence, and indicate if changes were made. The images or other third party material in this article are included in the article's Creative Commons licence, unless indicated otherwise in a credit line to the material. If material is not included in the article's Creative Commons licence and your intended use is not permitted by statutory regulation or exceeds the permitted use, you will need to obtain permission directly from the copyright holder. To view a copy of this licence, visit http://creativecommons.org/licenses/by/4.0/.

\section{References}

1. Wang T, Qin Y, Zhang J, Li X, Tong S, Zhao W, Zhang J (2020) An antiviral drug-resistant mutant of hepatitis B virus with high replication capacity in association with a large in-frame deletion in the preS1 region of viral surface gene. Virus Genes. https://doi. org/10.1007/s11262-020-01787-9

2. Peiffer KH, Kuhnhenn L, Jiang B, Mondorf A, Vermehren J, Knop V, Susser S, Walter D, Dietz J, Carra G, Finkelmeier F, Zeuzem S, Sarrazin C, Hildt E (2018) Divergent preS sequences in virionassociated hepatitis B virus genomes and subviral HBV surface antigen particles from HBV e antigen-negative patients. J Infect Dis 218(1):114-123. https://doi.org/10.1093/infdis/jiy119

3. Buckwold VE, Xu Z, Chen M, Yen TS, Ou JH (1996) Effects of a naturally occurring mutation in the hepatitis B virus basal core promoter on precore gene expression and viral replication. J Virol 70(9):5845-5851. https://doi.org/10.1128/ JVI.70.9.5845-5851.1996

4. Bruss V (1997) A short linear sequence in the pre-S domain of the large hepatitis B virus envelope protein required for virion formation. J Virol 71(12):9350-9357. https://doi.org/10.1128/ JVI.71.12.9350-9357.1997

5. Rabe B, Delaleau M, Bischof A, Foss M, Sominskaya I, Pumpens P, Cazenave C, Castroviejo M, Kann M (2009) Nuclear entry of hepatitis B virus capsids involves disintegration to protein dimers followed by nuclear reassociation to capsids. PLoS Pathog 5(8):e1000563. https://doi.org/10.1371/journal.ppat.1000563

6. Levrero M, Zucman-Rossi J (2016) Mechanisms of HBV-induced hepatocellular carcinoma. J Hepatol 64(1 Suppl):S84-S101. https ://doi.org/10.1016/j.jhep.2016.02.021

7. Lauer U, Weiss L, Hofschneider PH, Kekulé AS (1992) The hepatitis B virus pre-S/S(t) transactivator is generated by 3' truncations within a defined region of the S gene. J Virol 66(9):5284-5289. https://doi.org/10.1128/JVI.66.9.5284-5289.1992

8. Churin Y, Roderfeld M, Roeb E (2015) Hepatitis B virus large surface protein: function and fame. Hepatobiliary Surg Nutr 4(1):1-10. https://doi.org/10.3978/j.issn.2304-3881.2014.12.08

9. Hildt E, Saher G, Bruss V, Hofschneider PH (1996) The hepatitis $B$ virus large surface protein (LHBs) is a transcriptional activator. Virology 225(1):235-239. https://doi.org/10.1006/viro.1996.0594

10. Luan F, Liu H, Gao L et al (2009) Hepatitis B virus protein preS2 potentially promotes HCC development via its transcriptional activation of hTERT. Gut 58:1528-1537. https://doi.org/10.1136/ gut.2008.174029

11. Luan F, Liu B, Zhang J, Cheng S, Zhang B, Wang Y (2017) Correlation between $\mathrm{HBV}$ protein preS2 and tumor markers of hepatocellular carcinoma. Pathol Res Pract 213(9):1037-1042. https ://doi.org/10.1016/j.prp.2017.08.007

12. Teng CF, Li TC, Huang HY, Lin JH, Chen WS, Shyu WC, Wu HC, Peng CY, Su IJ, Jeng LB (2020) Next-generation sequencingbased quantitative detection of hepatitis B virus Pre-S mutants in plasma predicts hepatocellular carcinoma recurrence. Viruses 12(8):796. https://doi.org/10.3390/v12080796

Publisher's Note Springer Nature remains neutral with regard to jurisdictional claims in published maps and institutional affiliations. 